OPEN ACCESS

Edited by:

Qiangtai Huang,

Sun Yat-sen University, China

Reviewed by:

Pingping $\mathrm{Li}$

China University of Petroleum, China

Hongjian Zhu,

Yanshan University, China

*Correspondence:

Liang Wenfu

liangwf2049@163.com

Specialty section:

This article was submitted to

Geochemistry,

a section of the journal

Frontiers in Earth Science

Received: 24 August 2021

Accepted: 13 October 2021

Published: 22 December 2021

Citation:

Yingjie L, Wenfu L, Wang $\mathrm{H}$ and Zian L (2021) Response to the Variation of Clay Minerals During ASP Flooding in the Saertu Oilfield in the

Songliao Basin.

Front. Earth Sci. 9:764052

doi: 10.3389/feart.2021.764052

\section{Response to the Variation of Clay Minerals During ASP Flooding in the Saertu Oilfield in the Songliao Basin}

\author{
Liang Yingjie ${ }^{1,2}$, Liang Wenfu ${ }^{3 *}, \mathrm{He} \mathrm{Wang}^{1}$ and Li Zian ${ }^{4}$ \\ ${ }^{1}$ Key Lab of Mineral and Mineralization, Guangzhou Institute of Geochemistry, Chinese Academy of Sciences, Guangzhou, China, \\ ${ }^{2}$ Graduate Education, University of Chinese Academy of Sciences, Beijing, China, ${ }^{3}$ Second Oil Production Plant, Daqing Oilfield \\ Company Limited, Daqing, China, ${ }^{4}$ School of Marine Sciences, Sun Yat-sen University, Guangzhou, China
}

In this paper, the variation of clay minerals and their influence on reservoir physical properties and residual oil before and after ASP flooding are analyzed. The results show that the total amount of clay minerals in reservoirs decreases after ASP flooding in the ultra-high-water-cut-stage reservoirs of the Naner Zone in the Saertu Oilfield, Songliao Basin. Therein, the illite content reduces, while the content of illite smectite mixed-layer and chlorite increases. The content of kaolinite varies greatly. The content of kaolinite decreases in some samples, while it increases in other samples. The clay minerals block the pore throat after ASP flooding. As a result, the pore structure coefficient and the seepage tortuosity increase, the primary intergranular pore throat shrinks, and the pore-throat coordination number decreases. Nevertheless, the dissolution of clay minerals reduces the pore-throat ratio and increases porosity and permeability. The variation of clay minerals after ASP flooding not only intensifies the reservoir heterogeneity but also affects the formation and distribution of residual oil. The residual oil of the oil-clay mixed adsorption state is a newly formed residual oil type related to clay, which accounts for $44.2 \%$ of the total residual oil reserves, so it is the main occurrence form of the oil in reservoirs after ASP flooding. Therefore, the exploitation of this type of residual oil has great significance to enhance the oil recovery in ultra-highwater-cut-stage reservoirs.

Keywords: ASP flooding, clay minerals, pore structure and physical properties, residual oil, ultra-high water cut stage, the Songliao basin

\section{INTRODUCTION}

ASP flooding refers to a chemical flooding method that utilizes a composite system of alkali, surfactant, and polymer for petroleum exploitation. It is one of the enhanced oil recovery (EOR) technologies used in many ultra-high-water-cut-stage reservoirs (Zhang et al., 2009; Cheng et al., 2012; Cheng et al., 2014; Wu et al., 2015a; Xv et al., 2015). A large amount of studies indicates that the composition, distribution, and content of clay minerals in the reservoirs have a great influence on the pore structure and physical properties (e.g., porosity and permeability), which will directly affect the oil production efficiency (Chen et al., 2016; Zhao et al., 2017; Zhu et al., 2021). There are many physical and chemical reactions between pore fluids and rock components in the formation during ASP flooding (Song et al., 2011; Wu et al., 2015a; Song et al., 2015; Sheng., 2016), especially the strong water-rock reaction of clay minerals. Pore structure and physical properties in 


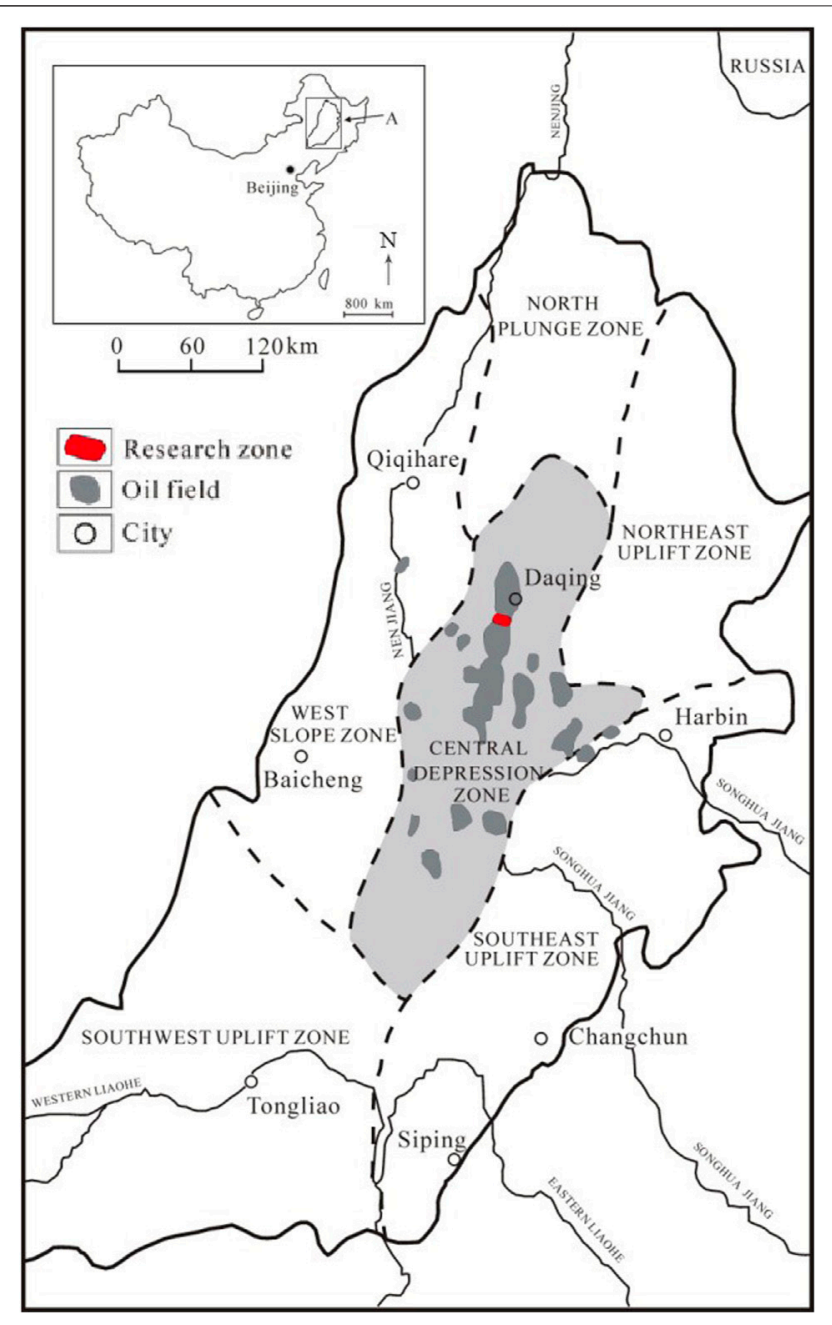

FIGURE 1 | Location of the Naner Zone in the Saertu Oilfield (A: Location of the Songliao Basin). reservoirs change under the chemical dissolution of rock minerals and the precipitation and agglomeration of clay mineral particles in the pore fluid because of the adsorptionflocculation of the polymer (Kazempour et al., 2013; Huang et al., 2020). Ultimately, all these changes of the pore structure and physical properties of reservoirs will affect the formation and distribution of residual oil (Liu et al., 2013; Liu et al., 2014; Liu et al., 2015; Mansa et al., 2017; Wu et al., 2015b). Therefore, it is significant for the effective development of residual oil to investigate the variation of clay minerals after ASP flooding in ultra-high-water-cut-stage reservoirs. In the paper, the response to the variation of clay minerals in reservoirs during ASP flooding is studied for the ultra-high-water-cut-stage reservoirs of the Naner Zone in the Saertu Oilfield, Songliao Basin. Besides, the effect of these variations on pore structure, physical properties, and residual oil distribution are also investigated. The results of this study provide technical support for the effective development of residual oil after ASP flooding.

\section{GEOLOGICAL SETTING}

The Naner Zone (research zone) of the Saertu Oilfield is located in the northern part of Daqing Placanticline from the Songliao Basin (Figure 1) (Hu et al., 2005). Three sets of oil reservoirs (Saertu, Putaohua, and Gaotaizi) are developed in the Naner Zone (Figure 2). These reservoirs belong to the fluern part of the daqivial-delta deposition, and their burial depth is about 827-1,200 m (Sui et al., 2000; Zhao et al., 2000). In this study, the second segment of the Saertu reservoir (member Sa II) is selected as the target layer.

Member Sa II is a sandstone reservoir with good permeability, and its thickness is about $52-56 \mathrm{~m}$. The sandstone type is arkose, and a small part is hard sandy arkose with a fine sand-like structure. The detrital minerals are mainly composed of feldspar and quartz. Feldspar accounts for $43 \%-54 \%$ of the total content, consisting of a large amount of orthoclase and a small amount of plagioclase and microcline. In addition, quartz accounts for $30 \%-43 \%$ of the total content. The cement is mainly composed of argilla, and the argillaceous content is more than $3 \%$. The clay mineral composition of cement is mainly kaolinite, followed by chlorite, illite, and illite smectite mixed layers. The cementation type is pore-contact, and the intergranular pore is the main type of pores (Xing and Jiang, 1993; Gao, et al., 2015).

At present, ASP flooding has been conducted on the Sa II reservoir, that is, injection of an alkali (sodium hydroxide)-surfactant (petroleum sulfonate)-polymer (polyacrylamide) system to the Sa II reservoir for oil displacement. The injection concentrations of the ASP system of alkali, surfactant, and polymer are 1.2, 0.3 , and $0.18 \mathrm{wt} \%$, respectively. The molecular weight of the polymer is 25 million. The salinities of formation water before and after ASP flooding are 7,178 and $7,463 \mathrm{mg} / \mathrm{L}$, respectively, and the type of formation water is sodium bicarbonate $(\mathrm{NaHCO})$.

\section{MATERIALS AND METHODS}

\section{Materials}

The core samples required for this study were collected from the Sa II reservoir of the Saertu Formation in the Naner Zone of the Saertu Oilfield, and the core depth is $930-943 \mathrm{~m}$. A total of 10 core samples were taken, including five ASP flooding samples with an average air permeability of $0.638 \mu \mathrm{m}^{2}$ and an average porosity of $27.9 \%$ and five water flooding samples (before ASP flooding) with an average air permeability of $0.443 \mu \mathrm{m}^{2}$ and an average porosity of $26.9 \%$. The lithologies are all oil-bearing siltstones with good reservoir properties.

\section{Methods}

Scanning electron microscopy (SEM) and X-ray diffraction methods were applied to the surface morphology, and wholerock mineral and clay mineral analysis of the core samples was conducted to determine the pore structure and mineral composition of the cores and to explore the characteristics of 


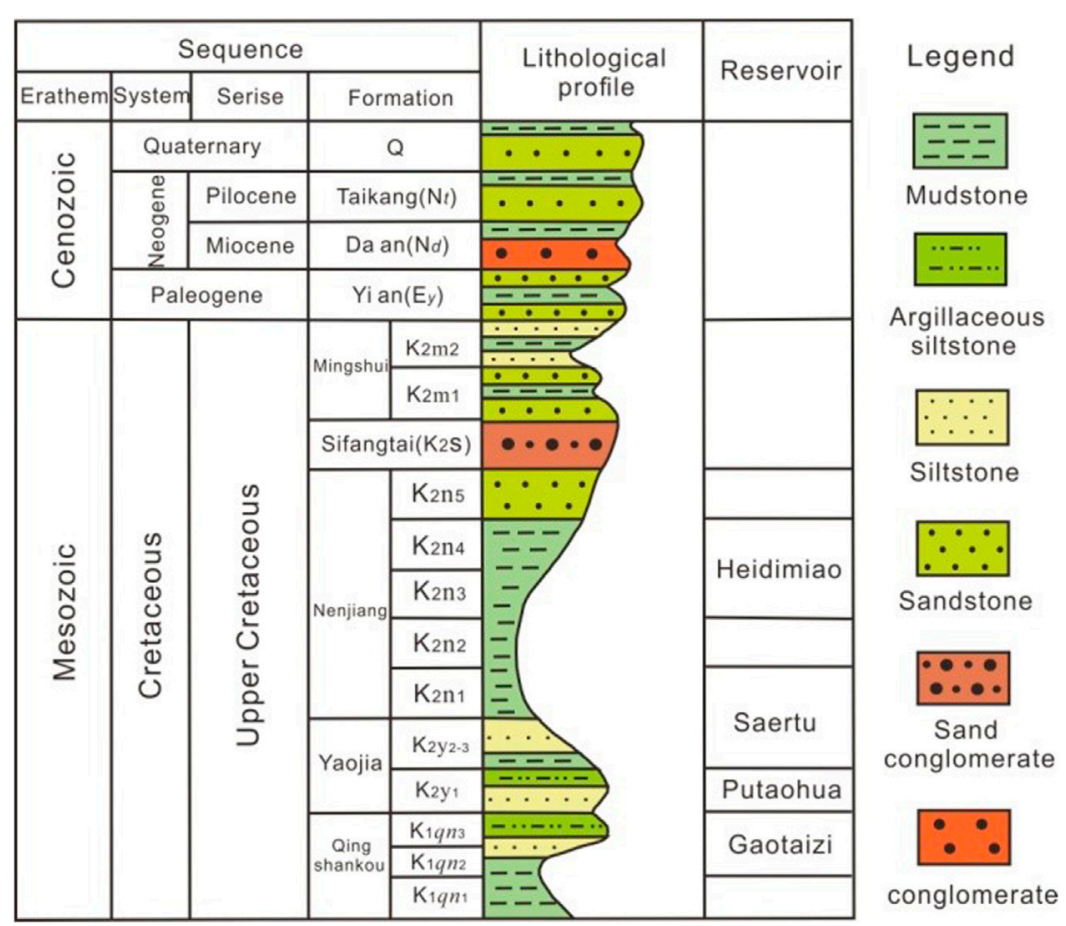

FIGURE 2 | Profile map of the different reservoirs in the Naner Zone.

changes in the pore structure and clay minerals of the cores before and after ASP flooding (Fang, et al., 2016; Zhu et al., 2021).

\section{Scanning Electron Microscope Analysis Method}

SEM was used to directly observe the morphology and pore structure of core samples, including the shape, size, and distribution characteristics of pores, inter-pore connectivity, and the distribution characteristics of solid particle skeleton and clay minerals (Houben et al., 2013; Zhu et al., 2018). A scanning electron microscope was used to observe the samples, which were then firstly dried by the critical point drying method, i.e., using the property that the surface tension of a substance is equal to zero at the critical state to completely vaporize the liquid of the sample and exhaust it as a gas to achieve the purpose of complete drying. Then the sample is treated with conductive treatment to make the sample surface conductive. In this paper, the metal coating method is used, which uses a special device to cover the sample surface with metals of low resistivity, such as gold, platinum, and palladium, after evaporation.

\section{X-Ray Diffraction Analysis Method}

$\mathrm{X}$-ray diffraction is applied to the analysis of whole-rock minerals and clay minerals in core samples (Wang et al., 2019). To determine the core samples by X-ray diffraction, the natural orientation sheet $(\mathrm{N})$ is firstly prepared by the extraction method; i.e., start the vacuum pump, put the soaked microporous filter membrane on the funnel, pour the suspension in several times, pump the suspension in $10 \mathrm{~min}$ each time, remove the filter membrane when the clay membrane reaches a thickness of $30-40 \mu \mathrm{m}$, put the membrane on the slide backward, and put it in the culture blood to dry. Then the naturally oriented slides were thermostated with ethylene glycol vapor at $45^{\circ} \mathrm{C}$ for $7 \mathrm{~h}$ and cooled to room temperature to make ethylene glycol-saturated slides (EG), and the ethylene glycol-saturated slides were thermostated at $(550+10)^{\circ} \mathrm{C}$ for $2 \mathrm{~h}$ and cooled naturally to room temperature to make heated slides $\left(550^{\circ} \mathrm{C}\right)$. And the ray diffraction spectra of the naturally oriented sheet $(\mathrm{N})$, glycoltreated sheet $(\mathrm{EG})$, and heated sheet $\left(550^{\circ} \mathrm{C}\right)$ were completed under certain experimental conditions. Finally, for the specific characteristics of clay minerals in sedimentary rocks, the percentages of every single mineral in clay minerals were calculated by taking advantage of the phenomenon where swelling minerals in clay minerals are heated and dehydrated and their crystalline spacing shrinks to $1.0 \mathrm{~nm}$, and the characteristic peaks of kaolinite and chlorite overlap at $0.7 \mathrm{~nm}$ in the diffractogram of natural orientation.

\section{VARIATION CHARACTERISTICS OF RESERVOIR CLAY MINERALS BEFORE AND AFTER ASP FLOODING}

\section{Morphology and Distribution Characteristics of Clay Minerals}

SEM images show that different types of clay minerals have different morphologies and distribution characteristics. Kaolinite is an alteration product of feldspar, and its 


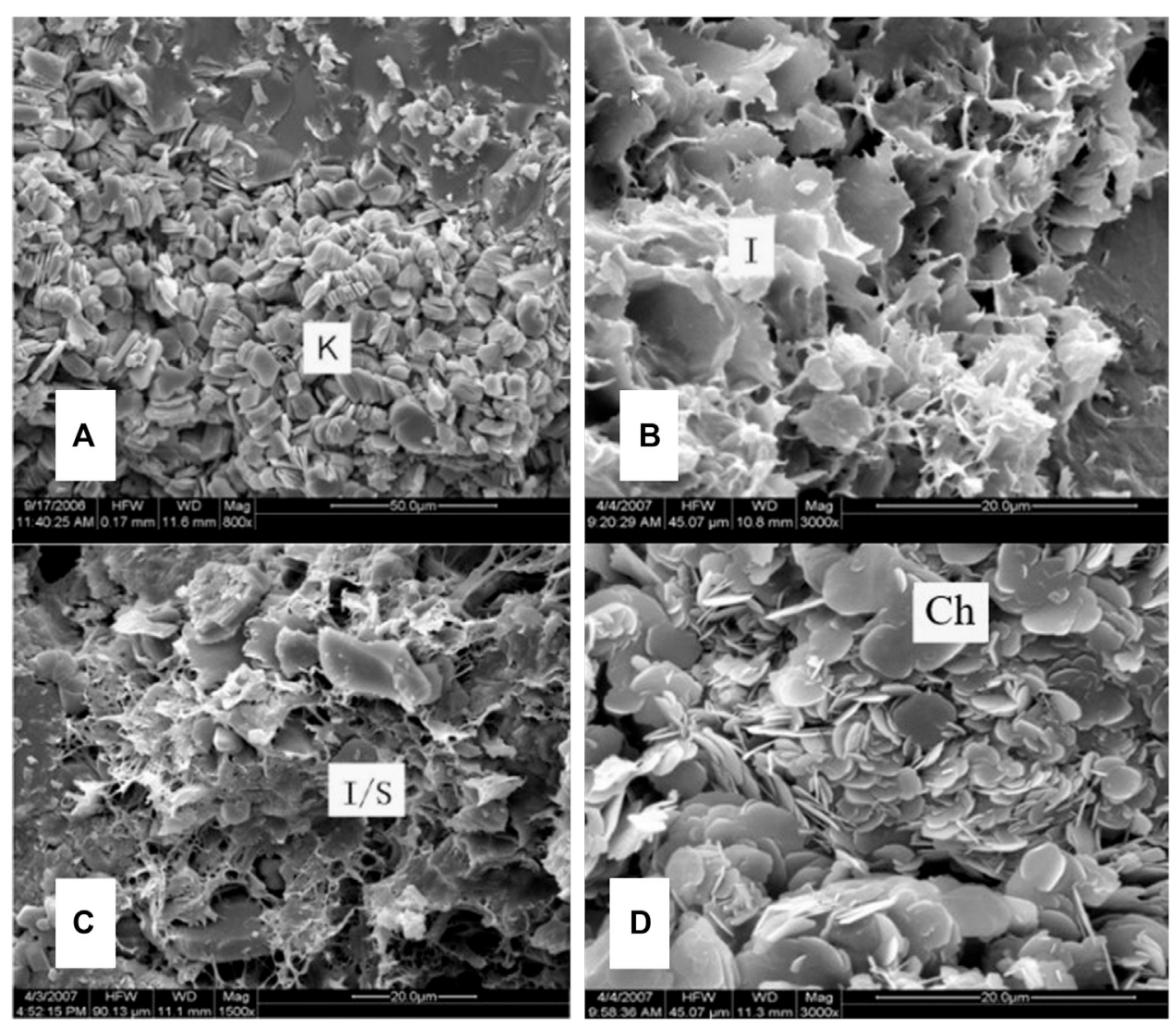

FIGURE 3 | SEM images of clay minerals [(A) kaolinite, (B) illite, (C) illite smectite mixed layer, (D) chlorite].

morphologies are book-page-like, worm-like, and accordionlike. Kaolinite is mostly distributed in the intergranular pores in the form of pore filling (Figure 3A). Kaolinite is easy to move with fluids under the scouring of fluids because of the loose intracrystalline structure and then block and divide the pores and throats. Therefore, kaolinite is an important velocitysensitive mineral. Illite is attached to the particle surface or filled in the intergranular pores in the form of leaves or silk hairs (Figure 3B). The leaf-like crystallites separate the pores into several fine pores, which increase the tortuosity of flow channels. The hair-like crystallites are easily washed away by water and then block pores and throats, which leads to the decrease of porosity and permeability of reservoirs. The illite smectite mixed layer is an intermediate product of montmorillonite transformed to illite, and its morphologies are burr and curl. It has three typical structures, namely, lamellar structure, honeycomb structure, and flocculent structure (Figure 3C). Compared with other clay minerals, the illite smectite mixed layer has very strong water sensitivity. Chlorite is often symbiotic with authigenic quartz, and its morphologies are needle-like, pompon-like, and roselike. The chlorite is distributed in pores in the form of pore filling and pore backing. Generally, the needle-like chlorite is mostly filled with pore backing on the surface of the particles, while the pompon-like and rose-like chlorites are filled in the pores (Figure 3D). Chlorite can be transformed from minerals such as biotite, hornblende, and montmorillonite. However, the authigenic chlorite is generally rich in high-valence iron ions, which easily react with the acid solution (e.g., $\mathrm{HCl}$ ) in the drilling fluid to cause precipitation and reservoir damage. Therefore, chlorite is an acid-sensitive mineral.

\section{Variation Characteristics of the Content and Composition of Clay Minerals}

The 10 selected core samples were extracted and dried at first, and then the X-ray diffraction method was used for the quantitative analysis of whole-rock minerals and clay minerals. The analysis results are presented in Table 1. As shown in Table 1, the alkali in the ASP system affects the content of the rock-forming minerals and clay mineral rock. The total amount of quartz is reduced after ASP flooding, and the potassium feldspar content is also reduced, while the plagioclase (albite) content increases slightly. Furthermore, the total content of clay minerals decreases after ASP flooding; therein, the relative content of the illite decreases, but the relative content of the chlorite and illite smectite mixed layer increases. However, the variation of kaolinite content in different core samples is quite different. Kaolinite contents in some samples decrease, while they increase in others. 
TABLE 1 | Variation of rock mineral composition and content before and after ASP flooding.

\begin{tabular}{|c|c|c|c|c|c|c|c|c|c|c|c|c|c|c|c|}
\hline \multirow[t]{2}{*}{ Core number } & \multirow[t]{2}{*}{ Depth (m) } & \multicolumn{4}{|c|}{$\begin{array}{l}\text { Mineral composition and } \\
\text { relative content }(\%)\end{array}$} & \multicolumn{2}{|c|}{$\begin{array}{l}\text { Mixed- } \\
\text { layer ratio } \\
(\% \mathrm{~S})\end{array}$} & \multicolumn{6}{|c|}{$\begin{array}{c}\text { Type and relative content } \\
\text { of clay mineral (\%) }\end{array}$} & \multirow[t]{2}{*}{$\begin{array}{c}\text { Total amount } \\
\text { of clay minerals (\%) }\end{array}$} & \multirow[t]{2}{*}{ Remark } \\
\hline & & Quartz & Potassium feldspar & Anorthose & Calcite & $\mathrm{I} / \mathrm{S}^{\mathrm{a}}$ & $\mathbf{C} / \mathbf{S}^{\mathbf{b}}$ & $\mathbf{S}^{c}$ & $I^{d}$ & $\mathbf{K}^{\mathbf{e}}$ & $c^{f}$ & I/S & $\mathrm{C} / \mathrm{S}$ & & \\
\hline W1 & 941.42 & 50.8 & 20.9 & 24.6 & - & 15 & - & - & 20 & 69 & 4 & 7 & - & 3.7 & Water flooding \\
\hline W2 & 941.44 & 51.9 & 21.7 & 22.8 & - & 15 & - & - & 18 & 71 & 6 & 5 & - & 3.6 & Water flooding \\
\hline W3 & 941.99 & 52.5 & 19.8 & 23.5 & 0.3 & 15 & 37 & - & 8 & 73 & 5 & 5 & 9 & 3.9 & Water flooding \\
\hline W4 & 942.01 & 48.4 & 26.5 & 21.6 & - & 15 & - & - & 15 & 76 & 6 & 3 & - & 3.5 & Water flooding \\
\hline W5 & 942.03 & 50.2 & 21.6 & 22.1 & - & 15 & - & - & 10 & 77 & 8 & 5 & - & 6.1 & Water flooding \\
\hline S1 & 941.43 & 38.9 & 17.8 & 39.8 & - & 20 & - & - & 3 & 83 & 8 & 6 & - & 3.5 & ASP flooding \\
\hline S2 & 942.00 & 37.1 & 18.2 & 41.1 & - & 20 & - & - & 2 & 85 & 6 & 7 & - & 3.6 & ASP flooding \\
\hline S3 & 942.07 & 36.2 & 18.6 & 42.8 & - & 20 & - & - & 8 & 58 & 20 & 14 & - & 2.4 & ASP flooding \\
\hline S4 & 942.13 & 34.8 & 18.9 & 42.9 & - & 20 & - & - & 7 & 56 & 21 & 16 & - & 3.4 & ASP flooding \\
\hline S5 & 942.14 & 44.3 & 16.9 & 35.7 & - & 20 & - & - & 4 & 61 & 18 & 17 & - & 3.1 & ASP flooding \\
\hline
\end{tabular}

allite smectite mixed mineral.

${ }^{b}$ Chlorite smectite mixed mineral.

${ }^{c}$ Smectite.

${ }^{d}$ llite.

${ }^{e}$ Kaolinite.

${ }^{f}$ Chlorite.

In addition, ASP flooding changes the chemical composition of the rock. The ASP system injected into the reservoir, especially the alkali, on the one hand, will dissolve the rock minerals (e.g., kaolinite and feldspar), thereby causing the elemental components (e.g., silicon and aluminum) in the rock minerals to be transferred from the solid phase to the formation water; on the other hand, the aluminum and silicon ions which are dissolved by the alkali will regenerate the crystalline precipitate of aluminosilicate in other places under certain conditions (Maggio et al., 2010; Wu et al., 2015a; Song et al., 2015).

The feldspar of rock-forming minerals and some kaolinites are mostly eroded by alkali in the ASP flooding system. As a nonexpanded clay mineral, kaolinite is one of the most common authigenic clay minerals in sandstone reservoirs, and it is also an indicator mineral for feldspar dissolution (Xing, 1983). The feldspar can generate kaolinite under eluviation, and its chemical reaction is as follows:

$$
\begin{aligned}
& (\mathrm{K}, \mathrm{Na}, \mathrm{Ca})\left[\mathrm{AlSi}_{3} \mathrm{O}_{8}\right]+\mathrm{H}^{+} \rightarrow \mathrm{Al}_{2} \mathrm{Si}_{2} \mathrm{O}_{5}(\mathrm{OH})_{4}+\left(\mathrm{K}^{+}, \mathrm{Na}^{+}, \mathrm{Ca}^{2+}\right) \\
& \quad+\mathrm{Si}^{4+}
\end{aligned}
$$

The reaction equation for the dissolution of kaolinite by alkali is as follows:

$$
\mathrm{Al}_{4}\left[\mathrm{Si}_{4} \mathrm{O}_{10}\right](\mathrm{OH})_{8}+8 \mathrm{OH}^{-}=4 \mathrm{Al}(\mathrm{OH})_{3} \downarrow+4 \mathrm{SiO}_{3}^{2-}+2 \mathrm{H}_{2} \mathrm{O} .
$$

Kaolinite can be transformed into albite under the action of alkali, and the reaction equation is as follows:

$$
\begin{aligned}
& \mathrm{Al}_{2}\left[\mathrm{Si}_{2} \mathrm{O}_{5}\right](\mathrm{OH})_{4}+2 \mathrm{Na}^{+}+2 \mathrm{OH}^{-}+4 \mathrm{Si}(\mathrm{OH})_{4}=2 \mathrm{NaAlSi}_{3} \mathrm{O}_{3} \\
& +11 \mathrm{H}_{2} \mathrm{O} .
\end{aligned}
$$

It can be concluded that the increase of anorthose content after ASP flooding is due to the formation of albite from kaolinite under the action of alkali. The content of the illite smectite mixed layer is increased, which is the aluminosilicate scale formed by mineral recrystallization (Lu and Guan, 1999). There are two reasons for the increase in kaolinite content. One is the newly formed kaolinite by feldspar under eluviation, and the other is the precipitation and accumulation of kaolinite particles in formation water caused by the adsorption flocculation of the polymer in the ASP system (Liu et al., 2014; Mansa et al., 2017). The increase in chlorite content is an aluminosilicate precipitate formed by mineral recrystallization in an alkaline environment.

\section{INFLUENCE OF VARIATION OF CLAY MINERALS ON RESERVOIR PHYSICAL PROPERTIES}

\section{Influence on the Pore Structure of Reservoir}

It can be seen from the SEM images of core samples before ASP flooding that the core intergranular pores include the primary intergranular pores and the secondary intergranular pores. The main cements in the core are clay minerals. Among the clay mineral cements, it can be seen from Figure $\mathbf{4 A}$ that the kaolinite cements in the pores in the form of pore-filling and blocks the pore throats; parts of illite and chlorite are cemented on the surface of the particles in the form of pore-backing to decrease the pore space, and the other part is cemented in the pores in the form of pore-filling and blocks the pore throats (Figure 4B).

It can be seen from the SEM images of core samples after ASP flooding that the clay minerals block the pore throat, and the pore structure coefficient and the tortuosity of pore throat increase after ASP flooding. The kaolinite and illite in the clay minerals adhere to the surface of the rock particles and extend into the pore space, thereby causing the shrinkage of the primary intergranular pore throat (Figure 5A). In addition, the local pore throat is enlarged due to the dissolution of clay minerals and rock particles by alkali (Figure 5B). 

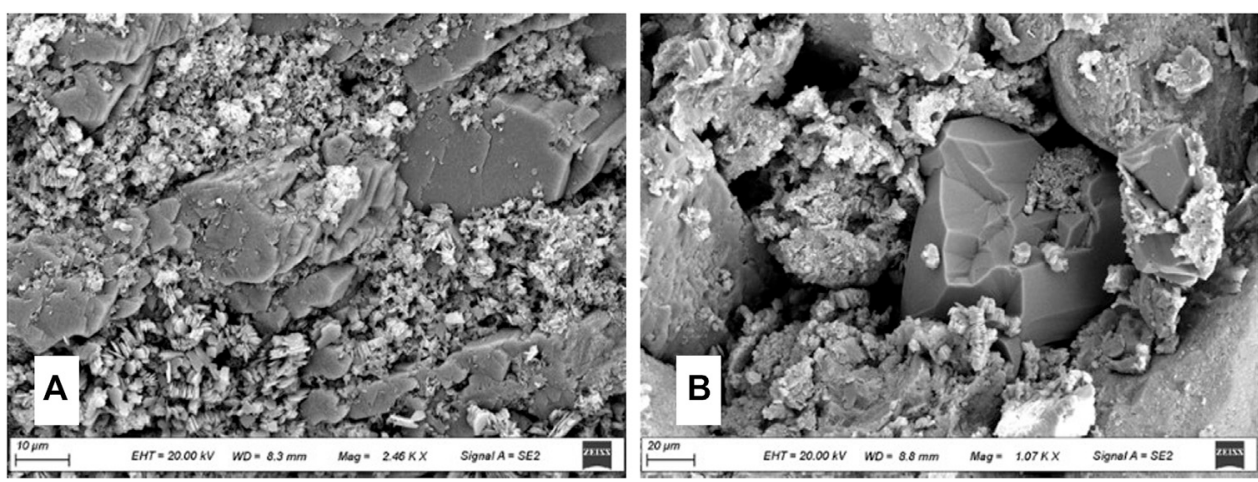

FIGURE 4 | Intergranular pore morphology before ASP flooding (A: surface of particles and pore throats, B: pore throats).
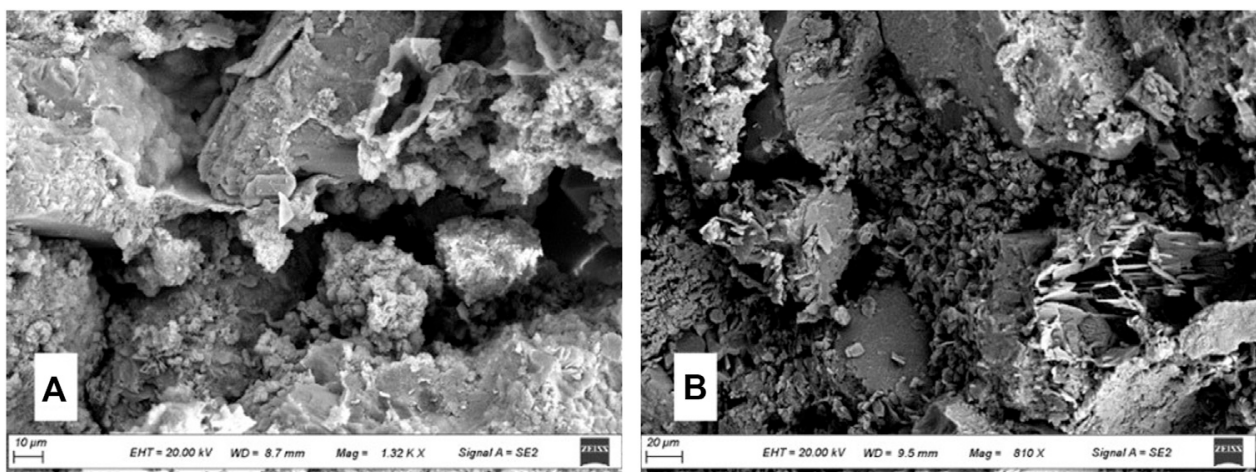

FIGURE 5 | Intergranular pore morphology after ASP flooding (A: primary intergranular pore throat, B: local pore throat).

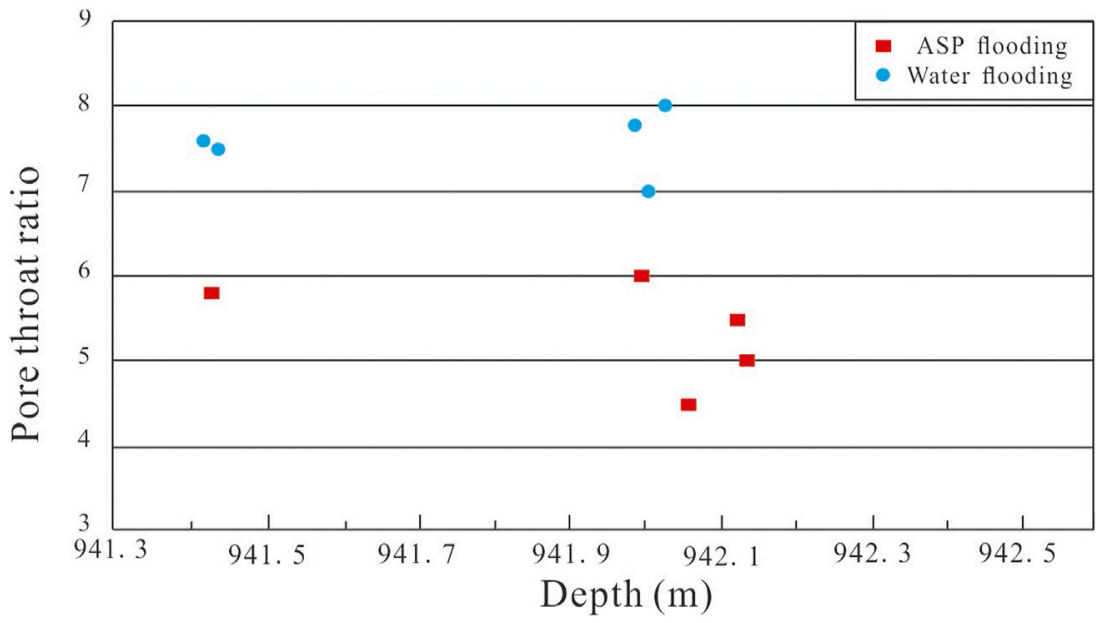

FIGURE 6 | Variation characteristics of pore-throat ratio before and after ASP flooding.

In addition, according to the analysis of the 3D nondestructive core sample pore structure obtained by CT scanning, the reservoir pore-throat ratio (ratio of pore radius and throat radius) and pore throat coordination number (throat number connecting each pore) decreased significantly after ASP flooding (Figure 6 and Figure 7). The reason for this phenomenon is that the alkali component in the ASP system erodes the clay minerals and rock particles (feldspar) in the 


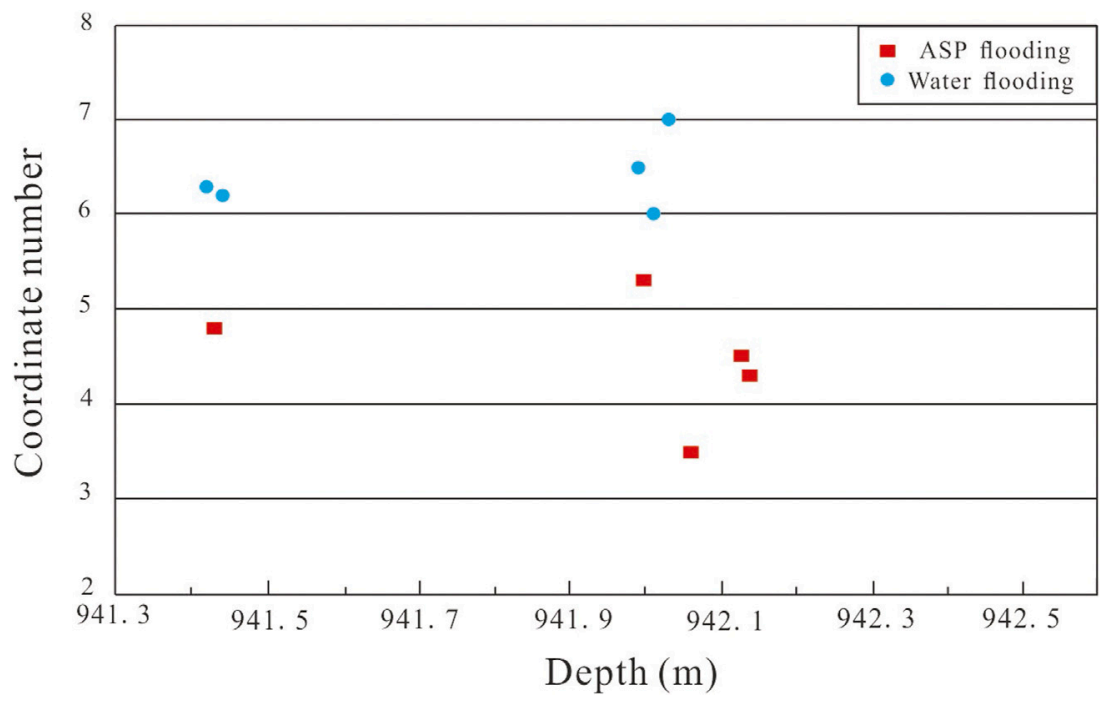

FIGURE 7 | Variation characteristics of pore throat coordinate number before and after ASP flooding.

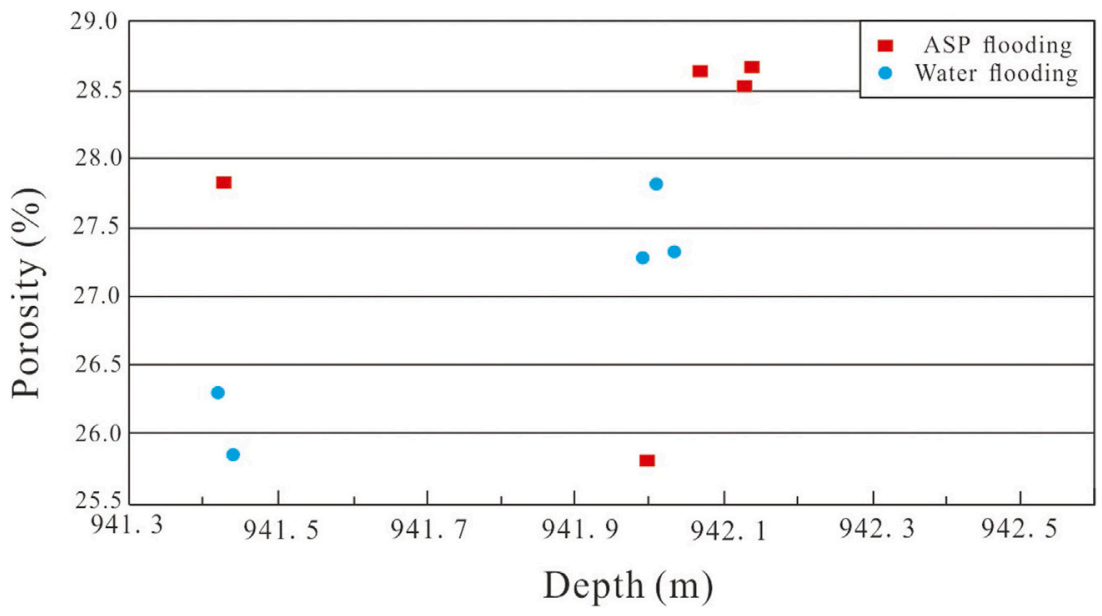

FIGURE 8 | Variation characteristics of porosity before and after ASP flooding.

reservoir during ASP flooding. The clay minerals and rock particles are chemically unstable, which are then dissolved by alkali migrating with the composite system, thereby increasing the diameter of the local pore throat (Loucks et al., 2012). In addition, the fine particles in reservoir fluids are easily adsorbed, trapped, and retained in the narrow throat by the polymer, causing throat blockage and reducing the effective communication in throats.

\section{Influence on Porosity and Permeability of Reservoir}

Figure 8 and Figure 9 show the physical properties of core samples before and after ASP flooding; we can conclude that the changing trends of porosity and permeability are consistent after
ASP flooding. The average porosity of the core samples increases, which is $0.97 \%$ higher than the value before ASP flooding. Sixty percent of the core porosity increases by more than $28 \%$, and the maximum value is $28.66 \%$. The core permeability after ASP flooding is mainly distributed between 663.19 and $882.88 \mathrm{mD}$. Compared with that of the cores before ASP flooding, the permeability increases significantly, and the increment is $195.09 \mathrm{mD}$. The influence of ASP flooding on the physical properties of cores is mainly caused by the dissolution of rock skeleton, clay minerals, and cuttings by alkali components in the ASP system (Olajire, 2014). Part of the pore throats become large because of alkali dissolution and fine particle migration; therefore, the physical properties become better. However, some parts of pore throats become smaller, and the tortuosity of the pore throat increases because of the accumulation and 


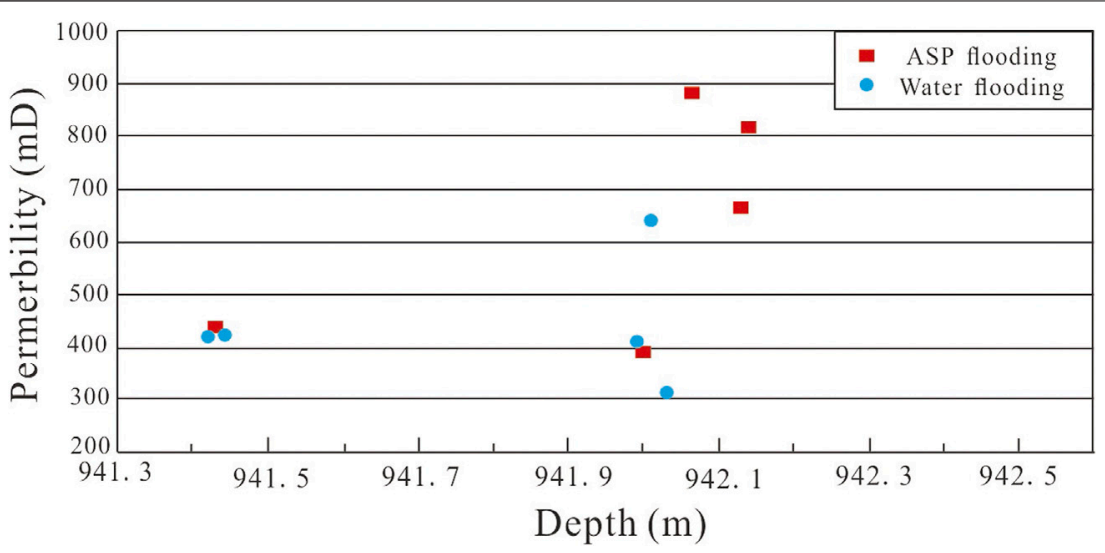

FIGURE 9 | Variation characteristics of permeability before and after ASP flooding.

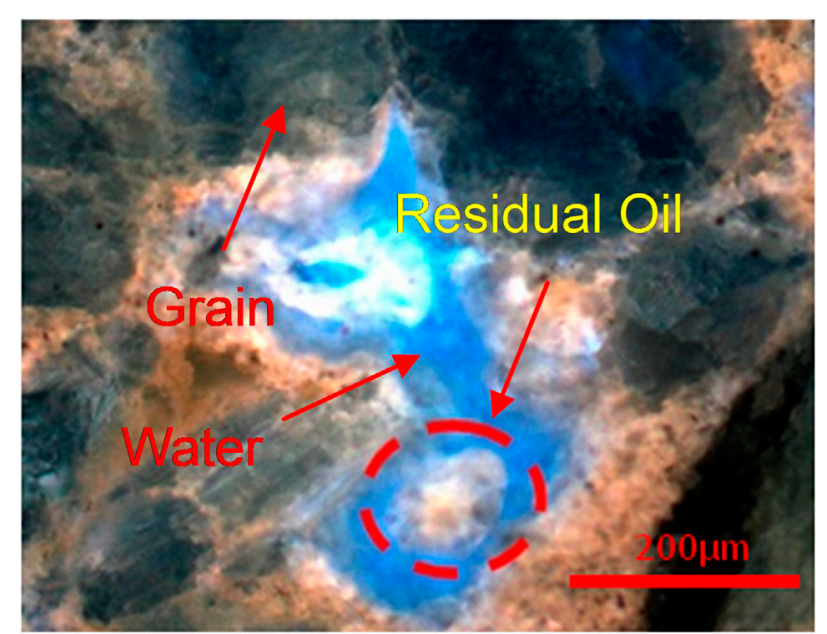

FIGURE 10 | Distribution of petroleum-clay mixed residual oil.

precipitation of fine particles in the pore fluids, thereby leading to a decrease in porosity and permeability. The porosity and permeability of the reservoir are polarized and the heterogeneity is enhanced after ASP flooding.

\section{INFLUENCE OF VARIATION OF CLAY MINERALS ON RESIDUAL OIL}

The transformation of clay minerals leads to changes in the pore structure of the reservoir, which affects the formation and distribution of residual oil. It can be seen from the fluorescence images of core samples after ASP flooding in ultra-high-water-cutstage reservoirs that there are many isolated "petroleum-clay mixed" residual oil in the middle of pores after ASP flooding (Figure 10).

At present, the Naner Zone in the north of Daqing placanticline in Songliao Basin has entered the stage of ultra- high water cut development. The kaolinite in the Sa II reservoir is a velocity-sensitive mineral. The kaolinite aggregation has poor adhesion to the skeleton particles, and the binding force between kaolinite wafers is also very weak. The kaolinite lamellar crystal aggregation is mechanically and chemically eroded by the injected ASP flooding solutions, causing the crystal skeleton of aggregation to be destroyed to form fine particles. In addition, the feldspar eluviation also produces new kaolinite. These tiny mineral fragments or newly formed kaolinite are driven by the injection fluid flow to produce particle migration. Then, the kaolinite particles migrating with the fluid are mixed with the microspheres of emulsified crude oil and are adsorbed and accumulated by the polymer in the local intergranular pores (Zhang et al., 2007; Zhang et al., 2010; Ren et al., 2015; Mansa et al., 2017). As a result, the isolated petroleum-clay mixed residual oil is formed and distributed in the intergranular pores and pore throats of the reservoir (Figure 10). The laser confocal scanning microscopy technique was used to quantify the proportion of different types of residual oil (Liang et al., 2018). The average content of petroleum-clay mixed residual oil is $4.8 \%$ (a percentage of the total volume of the sample), accounting for $44.2 \%$ of the total residual oil reserves. Compared with the core samples before the ASP flooding, the proportion of petroleumclay mixed residual oil content in the total residual oil reserves after ASP flooding increased by $12.9 \%$. The petroleum-clay mixed residual oil associated with clay minerals is the main occurrence state of residual oil after ASP flooding.

\section{CONCLUSION}

1) After ASP flooding, the total amount of clay minerals decreases, and the content of illite decreases, while the contents of the illite smectite mixed layer and chlorite increase. The kaolinite content varies greatly. On the one hand, the kaolinite is dissolved by alkali, and its content decreases; on the other hand, the kaolinite particle in pore fluid precipitates and gathers under the adsorption flocculation of the polymer, and its content increases. 
Because kaolinite can block the reservoir pore throat, it increases the difficulty of subsequent enhanced oil recovery (EOR).

2) After ASP flooding, the clay minerals block the pore throat, increase the tortuosity of pore fluid flow, and shrink the original intergranular pore throats. In addition, the dissolution of the clay minerals enlarges the local pore throat, decreases the pore-throat ratio and coordination number, and increases the porosity and permeability. Variation of clay minerals after ASP flooding not only enhances the reservoir heterogeneity but also influences the formation and distribution of residual oil.

3) The petroleum-clay mixed residual oil associated with clay minerals is a new type of residual oil. It is formed by the mixed aggregation of clay minerals and oil under the action of polymer in the process of ASP flooding and is mainly distributed in the intergranular pores or the pore throats with high clay mineral content. The clay-petroleum mixed oil is the main occurrence state of residual oil after ASP flooding, and the development of this type of residual oil will greatly improve the oil recovery of ultra-high-water-cut-stage oilfields.

\section{REFERENCES}

Chen, S., Han, Y., Fu, C., Zhang, h., Zhu, Y., and Zuo, Z. (2016). Micro and NanoSize Pores of clay Minerals in Shale Reservoirs: Implication for the Accumulation of Shale Gas. Sediment. Geology. 342 (aug.1), 180-190. doi:10.1016/j.sedgeo.2016.06.022

Cheng, J. C., Wu, J. Z., and Hu, J. Q. (2014). Key Theories and Technologies for Enhanced Oil Recovery of Alkaline/surfactant/polymer Flooding. Acta Petrolei Sinica 35 (2), 310-318. (in Chinese with English abstract). doi:10.7623/ syxb201402011

Cheng, J. C., Xu, D. P., Sui, X. G., and Wang, H. W. (2012). “The First Successful Field Demonstration of Alkaline Surfactant and Polymer Flooding through Thin Layer," in Abu Dhabi International Petroleum Conference and Exhibition, Abu Dhabi, UAE, November 11-14, 2012, SPE. doi:10.2118/161306-ms

Fang, W., Jiang, H., Li, J., Li, W., Li, J., Zhao, L., et al. (2016). A New Experimental Methodology to Investigate Formation Damage in clay-bearing Reservoirs. J. Pet. Sci. Eng. 143, 226-234. doi:10.1016/j.petrol.2016.02.023

Gao, Y., Wang, C., Liu, Z., Du, X., and Ibarra, D. E. (2015). Diagenetic and Paleoenvironmental Controls on Late Cretaceous clay Minerals in the Songliao basin, Northeast china. Clays Clay Miner. 63 (6), 469-484. doi:10.1346/ ccmn.2015.0630605

Houben, M. E., Desbois, G., and Urai, J. L. (2013). Pore Morphology and Distribution in the Shaly Facies of Opalinus Clay (Mont Terri, Switzerland): Insights from Representative 2D BIB-SEM Investigations on $\mathrm{Mm}$ to $\mathrm{Nm}$ Scale. Appl. Clay Sci. 71 (JAN), 82-97. doi:10.1016/j.clay.2012.11.006

Hu, W. S., Lu, B. Q., and Zhang, W. J. (2005). An Approach to Tectonic Evolution and Dynamics of the Songliao Basin. Chin. J. Geology. 40, 16-31. Chinese Cite Code: 0563-5020(2005)01-0016-16.

Huang, B., Wang, C., Zhang, W., Fu, C., Liu, H., and Wang, H. (2020). Study on the Stability of Produced Water from Alkali/surfactant/polymer Flooding under the Synergetic Effect of Quartz Sand Particles and Oil Displacement Agents. Processes 8 (3), 315. doi:10.3390/pr8030315

Kazempour, M., Manrique, E. J., Alvarado, V., Zhang, J., and Lantz, M. (2013). Role of Active Clays on Alkaline-Surfactant-Polymer Formulation Performance in sandstone Formations. Fuel 104 (2013), 593-606. doi:10.1016/ j.fuel.2012.04.034

Liang, Y. J., Li, Z. A., Li, J., and Sun, X. D. (2018). "Distribution of Microscopic Remaining Oil after ASP Flooding in Saertu Oilfield in Daqing," in Proceedings of the International Field Exploration and Development Conference 2018,

\section{DATA AVAILABILITY STATEMENT}

The original contributions presented in the study are included in the article/Supplementary Material; further inquiries can be directed to the corresponding author.

\section{AUTHOR CONTRIBUTIONS}

YL was responsible for the main experiment, analysis, and part of the writing work; WL was responsible for the data sorting and revision work; HW was responsible for part of the writing work and revision work. ZL was responsible for the experimental design and part of the writing work.

\section{FUNDING}

This study was supported by the National Science and Technology Major Project (Grant No. 2016ZX05054013).

Singapore, October 2019. Springer Series in Geomechanics and Geoengineering, 1653-1662. doi:10.1007/978-981-13-7127-1_158

Liu, Y. K., Cai, L. Z., Qu, G. H., and Wang, F. J. (2013). Research on Microscopic Characteristics of Remaining Oil Distribution after Strong Alkali ASP Flooding by Laser Scanning Confocal Technology. Sustain. Dev. Nat. Resour. 616-618, 757-761. doi:10.4028/www.scientific.net/AMR.616-618.757

Liu, G., Jiang, H., and Min, W. (2014). Study on Calculation for Polymer Flooding Incremental Oil. Pet. Geology. Recovery Efficiency 21 (2), 32-34+50. (in Chinese with English abstract). doi:10.13673/j.cnki.cn37-1359/te.2014.02.008

Liu, Y. K., Fan, M., Zhang, D., Wang, F. J., Liang, S., and Zhao, X. Y. (2015). Microscopic Characteristics of the Remained Oil after ASP Flooding. Pet. Geology. Oilfield Dev. Daqing 34 (2), 117-120. (in Chinese with English abstract). doi:10.3969/j.issn.1000-3754.2015.02.023

Loucks, R. G., Reed, R. M., Ruppel, S. C., and Hammes, U. (2012). Spectrum of Pore Types and Networks in Mudrocks and a Descriptive Classification for Matrix-Related Mudrock Pores. AAPG Bulletin 96 (6), 1071-1098. doi:10.1306/08171111061

Lu, G. W., and Guan, J. T. (1999). Influence of Temperature on Wetting Coefficient of Oil-Water-Quartz System. J. Univ. Pet. , China 23 (5), 92-94. (in Chinese with English abstract).

Maggio, R. D., Gajo, A., and Wahid, A. S. (2010). Chemo-mechanical Effects in Kaolinite. Part 1: Prepared Samples. Géotechnique 61, 449-457. doi:10.1680/ geot.8.P.067

Mansa, R., Piegang, G. B. N., and Detellier, C. (2017). Kaolinite Aggregation in Book-like Structures from Non-aqueous media. clays clay miner 65 (3), 193-205. doi:10.1346/ccmn.2017.064059

Olajire, A. A. (2014). Review of Asp Eor (Alkaline Surfactant Polymer Enhanced Oil Recovery) Technology in the Petroleum Industry: Prospects and Challenges. Energy 77 (dec), 963-982. doi:10.1016/j.energy.2014.09.005

Ren, C. H., Luo, Y., Wang, L. H., Jin, Y. X., Wang, T., Feng, X., et al. (2015). Investigation on Crude Oil Emulsification and Oil Displacement Technology. Adv. Fine Petrochemicals 16 (4), 12-15. (in Chinese with English abstract). doi:10.13534/j.cnki.32-1601/te.2015.04.004

Sheng, J. J. (2016). Formation Damage in Chemical Enhanced Oil Recovery Processes. Asia-pac. J. Chem. Eng. 11, 826-835. doi:10.1002/apj.2035

Song, K. P., He, J. G., and Yang, J. (2015). Influence of Base ASP Flooding on the Reservoir Pore Structure. J. China Univ. Pet. 39 (5), 164-172. (in Chinese with English abstract). doi:10.3969/j.issn.1673-5005.2015.05.023

Song, W. L., Pan, J., and Gao, Y. H. (2011). Effect of clay Content on the Adsorption Loss of Surfactant in Asp Floods Systems. Amr 225-226, 158-161. doi:10.4028/ www.scientific.net/amr.225-226.158 
Sui, J., Zhao, H. Q., and Lv, X. G. (2000). Study of Large Fluvial-delta Depositional Reservoir of Daqing Oilfield. Beijing: Petroleum Industry Press. (in Chinese).

Wang, Z. Z., Hu, R. T., Ren, G. H., Li, G. R., Liu, S. Y., Xu, Z. H., et al. (2019). Polyetheramine as an Alternative Alkali for Alkali/surfactant/polymer Flooding. Colloids Surf. A: Physicochemical Eng. Aspects 581, 123820. doi:10.1016/j.colsurfa.2019.123820

Wu, C. Y., Hou, J. R., Zhao, F. L., Zhang, F. M., Hao, H. D., and Liu, G. (2015a). Study on the Microscopic Mechanism of Driving Remaining Oil by ASP Compound System after Water Flooding. Pet. Geology. Recovery Efficiency 22 (5), 84-88. (in Chinese with English abstract). doi:10.13673/j.cnki.cn371359/te.2015.05.012

Wu, X. L., Yin, Y. D., Wu, G. P., Lu, A. H., Hou, Z. W., Ding, H. R., et al. (2015b). Study on the Reaction of Alkali/Surfactant/Polymer and Reservoir Cores in Daqing Oilfield. Chem. Eng. Oil Gas 44 (5), 66-72. (in Chinese with English abstract). doi:10.3969/j.issn.1007-3426.2015.05.014

Xing, S. Q. (1983). Evolutional Characteristics of Authigenic Quartz and Feldspar in Sandstones and Their Geological Significance. Pet. Geology. Oilfield Dev. Daqing 2 (3), 171-177. (in Chinese with English abstract).

Xing, S. Q., and Jiang, H. Q. (1993). Characteristics and Diagenesis of continental sandstone Reservoir in Songliao basin. Haerbin: Heilongjiang Science and Technology Press. (in Chinese).

Xv, Z. J., Wang, X., Wang, Y., and Pan, Y. (2015). Experimental Study on the Mechanism of ASP Flooding. Contemp. Chem. Industry 44 (1), 24-26. (in Chinese with English abstract). doi:10.13840/j.cnki.cn21-1457/ tq.2015.01.008

Zhang, L. J., Yue, X. A., and Guo, Z. J. (2010). Study on Emulsification of ASP Compound System with Daqing and Dagang Oil. Pet. Geology. Recovery Efficiency 17 (3), 74-76. (in Chinese with English abstract).

Zhang, X. J., Ji, W., Kang, Z. J., Sun, D. Y., Wang, J., and Na, R. X. (2009). The Development of the ASP Flooding Recovery Technique. Hangzhou Chem. Industry 39 (2), 5-8. (in Chinese).

Zhang, X. P., Hu, Y. H., Huang, H. J., and Deng, M. J. (2007). Aggregation Behavior of Ultrafine Kaolinite in Water. J. China Univ. Mining Tech. 36 (4), 514-517. (in Chinese with English abstract).
Zhao, H. Q., Fu, Z. G., Lv, X. G., Tian, D. H., and Wang, G. Y. (2000). Methods for Detailed Description of Large Fluvial-delta Depositional Reservoir. Acta Petrolei Sinica 21 (4), 109-113. (in Chinese with English abstract).

Zhao, Y. T., Sun, J., and Shan, X. L. (2017). Clay Minerals in an Oil-Sand deposit and Their Effect on Oil-Bearing Properties. Pet. Sci. Tech. 35 (6), 578-585. doi:10.1080/10916466.2016.1266366

Zhu, H., Huang, C., Ju, Y., Bu, H., Li, X., Yang, M., et al. (2021). Multi-scale MultiDimensional Characterization of clay-hosted Pore Networks of Shale Using FIBSEM, TEM, and X-ray Micro-tomography: Implications for Methane Storage and Migration. Appl. Clay Sci. 213, 106239. doi:10.1016/j.clay.2021.106239

Zhu, H., Ju, Y., Qi, Y., Huang, C., and Zhang, L. (2018). Impact of Tectonism on Pore Type and Pore Structure Evolution in Organic-Rich Shale: Implications for Gas Storage and Migration Pathways in Naturally Deformed Rocks. Fuel 228, 272-289. doi:10.1016/j.fuel.2018.04.137

Conflict of Interest: Author WL was employed by Daqing Oilfield Co., Ltd.

The remaining authors declare that the research was conducted in the absence of any commercial or financial relationships that could be construed as a potential conflict of interest.

Publisher's Note: All claims expressed in this article are solely those of the authors and do not necessarily represent those of their affiliated organizations, or those of the publisher, the editors, and the reviewers. Any product that may be evaluated in this article, or claim that may be made by its manufacturer, is not guaranteed or endorsed by the publisher.

Copyright $\odot 2021$ Yingjie, Wenfu, Wang and Zian. This is an open-access article distributed under the terms of the Creative Commons Attribution License (CC BY). The use, distribution or reproduction in other forums is permitted, provided the original author(s) and the copyright owner(s) are credited and that the original publication in this journal is cited, in accordance with accepted academic practice. No use, distribution or reproduction is permitted which does not comply with these terms. 